\title{
PENGARUH PENGENDALIAN INTERN, KEPATUHAN, ETOS KERJA \\ DAN KOMPENSASI MANAJEMEN TERHADAP PERILAKU ETIS \\ KARYAWAN (Studi Kasus : Toko Buku Gramedia Central Park Jakarta)
}

Oleh :

\author{
Galih Chandra Kirana, SE.,M.Ak \\ Dan \\ Aprita Wati
}

\section{Fakultas Ekonomi Program Studi Akuntansi Universitas Satya Negara Indonesia}

\begin{abstract}
ABSTRAK
Penelitian ini bertujuan (1) untuk mengetahui pengaruh Pengendalian Intern terhadap Perilaku Etis Karyawan, (2) untuk mengetahui pengaruh Kepatuhan terhadap Perilaku Etis Karyawan, (3) untuk mengetahui pengaruh Etos Kerja terhadap Perilaku Etis Karyawan, (4) untuk mengetahui pengaruh Kompensasi Manajemen terhadap Perilaku Etis Karyawan, (5) untuk mengetahui pengaruh Pengendalian Intern, Kepatuhan, Etos Kerja, dan Kompensasi Manajemen terhadap Perilaku Etis Karyawan Toko Buku Gramedia Central Park Jakarta.

Penelitian ini merupakan penelitian kausal komparatif (CausalComparative Research) dengan unit analisis yang diteliti adalah karyawan yang terdapat pada Toko Buku Gramedia Central Park Jakarta. Penelitian ini termasuk penelitian survei dengan jumlah sampel sebanyak 80 karyawan. Kuesioner di uji validitas dan reabilitasnya sebelum melakukan pengumpulan data penelitian. Alat uji yang digunakan dalam penelitian ini menggunakan uji asumsi klasik yang meliputi uji normalitas, uji multikolonieritas, uji heteroskedastisitas, uji regresi dan uji linearitas. Metode analisis data yang digunakan adalah analisis regresi berganda, uji korelasi dan koefisien determinasi.
\end{abstract}

Kata Kunci : Pengendalian Intern, Kepatuhan, Etos Kerja, Kompensasi Manajemen, Perilaku Etis Karyawan. 


\section{PENDAHULUAN}

\section{Latar Belakang Penelitian}

Sumber daya manusia merupakan faktor penentu keberhasilan pelaksanaan organisasi yang efektif. Tujuan ini tidak akan mungkin tercapai tanpa peran aktif karyawan bagaimanapun canggihnya alat-alat yang dimiliki, tidak ada artinya bagi perusahaan jika peran aktif sumber daya manusia nya tidak diikut sertakan. Melihat pentingnya sumber daya manusia, ada banyak karyawan yang bekerja dengan sungguh-sungguh atau berperilaku baik (etis) dalam suatu perusahaan, tetapi ada juga yang bekerja di luar kontrol sehingga dapat membawa karyawan ke arah perilaku yang tidak baik atau perilaku tidak etis.

Perilaku tidak etis timbul dalam suatu perusahaan disebabkan oleh lemahnya pengawasan manajemen yang dapat membuka keleluasaan karyawan untuk melakukan tindakan yang merugikan perusahaan. Perilaku tidak etis yang timbul menyebabkan kerugian dalam suatu perusahaan yaitu dapat mengakibatkan menurunnya nilai perusahaan. Maka dari itu perusahaan harus mempunyai sistem manajemen yang baik dan setiap aktivitas - aktivitas karyawan di dalam perusahaan harus mendapatkan pengawasan yang ketat dari manajer perusahaan.

Kepatuhan ini harus ditanamkan dalam diri karyawan terhadap semua peraturan-peraturan atau kode etik yang telah ditetapkan di dalam perusahaan. Hal ini bertujuan agar semua peraturan dan kegiatan yang ada dalam perusahaan dapat dijalankan oleh semua karyawan dan digunakan sebagai penilaian terhadap karyawan apakah karyawan berperilaku sesuai dengan aturan yang telah ditetapkan perusahaan atau menilai etis atau tidaknya perilaku karyawan dalam suatu perusahaan.

Etos Kerja merupakan suatu pandangan dan sikap suatu bangsa atau umat terhadap kerja (Anoraga,2009). Bila individu-individu dalam komunitas memandang kerja sebagai suatu hal yang luhur bagi eksistensi manusia, maka etos kerjanya akan cenderung tinggi. Sebaliknya sikap dan pandangan terhadap kerja sebagai sesuatu yang bernilai rendah bagi kehidupan, maka etos kerja dengan sendirinya akan rendah.

Faktor yang lainnya yang dapat mempengaruhi perilaku etis karyawan dalam perusahaan yaitu dengan adanya kompensasi manajemen. Kompensasi manajemen adalah berbagai bentuk imbalan yang diberikan organisasi kepada karyawan atas waktu, pikiran dan tenaga yang telah dikontribusikannya kepada organisasi. Kompensasi manajemen merupakan salah satu unsur penting dalam sistem pengendalian manajemen, karena sistem kompensasi dalam perusahaan bertujuan dapat mendorong dan meningkatkan kinerja karyawan, serta memberikan kepuasan terhadap prestasi kerja.

Adanya kasus tersebut dan pentingnya Pengendalian Intern, Kepatuhan, Etos Kerja, Kompensasi Manajemen dan Perilaku Etis Karyawan dalam setiap kegiatan perusahaan, maka mendorong penulis untuk melakukan penelitian dengan mengambil judul "Pengaruh Pengendalian Intern, Kepatuhan, Etos Kerja dan Kompensasi Manajemen Terhadap Perilaku Etis Karyawan" (Studi kasus Toko Buku Gramedia Central Park Jakarta). 


\section{Perumusan Masalah}

Dalam penelitian ini, peneliti merumuskan masalah sebagai berikut:

1. Apakah Pengendalian Intern berpengaruh terhadap Perilaku Etis Karyawan?

2. Apakah Kepatuhan berpengaruh terhadap Perilaku Etis Karyawan?

3. Apakah Etos Kerja berpengaruh terhadap Perilaku Etis Karyawan?

4. Apakah Kompensasi Manajemen berpengaruh terhadap Perilaku Etis Karyawan?

5. Apakah Pengendalian Intern, Kepatuhan, Etos Kerja, dan Kompensasi Manajemen berpengaruh terhadap Perilaku Etis Karyawan?

\section{Tujuan Penelitian}

Tujuan yang ingin dicapai dalam penelitian ini adalah :

1. Untuk mengetahui apakah terdapat pengaruh Pengendalian Intern terhadap Perilaku Etis Karyawan.

2. Untuk mengetahui apakah terdapat pengaruh Kepatuhan terhadap Perilaku Etis Karyawan.

3. Untuk mengetahui apakah terdapat pengaruh Etos Kerja terhadap Perilaku Etis Karyawan.

4. Untuk mengetahui apakah terdapat pengaruh Kompensasi Manajemen terhadap Perilaku Etis Karyawan.

5. Untuk mengetahui apakah terdapat pengaruh Pengendalian Intern, Kepatuhan, Etos Kerja, dan Kompensasi Manajemen terhadap Perilaku Etis Karyawan.

\section{LANDASAN TEORI}

\section{Teori Atribusi}

Teori Atribusi dikembangkan oleh Kelley (1967), kemudian Green serta Mitchell (1979) dalam Mohammad Glifandi (2011). Mereka berpandangan bahwa perilaku kepemimpinan disebabkan oleh atribut penyebab. Jadi teori kepemimpinan atribut menjelaskan mengapa perilaku kepemimpinan terjadi. Teori atribusi dikembangkan dengan beberapa pendapat berikut:

1. Teori Kepemimpinan Karismatik

Teori Atribusi ikut menjelaskan kepemimpinan karismatik. Para pengikut membuat atribut para pemimpin yang heroik atau yang memiliki kemampuan yang luar biasa yang mereka amati dan dapati.

2. Teori Kepemimpinan Transaksional

Para pemimpin transaksional adalah pemimpin yang membimbing atau mendorong bawahan mereka mengarah pada tujuan yang telah diletakkan, dengan cara menjelaskan peranan dan tugas yang dipersyaratkan.

3. Teori Kepemimpinan Transformasional

Terdapat juga para pemimpin yang tranformasional. Teori ini melihat pemimpin yang menyediakan pertimbangan individual dan stimulasi intelektual serta mereka yang memiliki karisma (Waworuntu,2003) dalam Mohammad Glifandi (2011). 


\section{Pengendalian Intern}

\section{Pengertian Pengendalian Intern}

Suatu sistem pengendalian internal terdiri dari kebijakan dan prosedur yang dirancang untuk memberikan manajemen jaminan yang wajar bahwa perusahaan mencapai tujuan dan sasarannya.

Pengendalian Intern berkaitan dengan proses-proses dan praktik-praktik dengan mana manajemen suatu organisasi berusaha untuk memastikan bahwa keputusan-keputusan dan aktivitas-aktivitas yang disetujui benar-benar diambil dan dilaksanakan (Sukrisno Agoes, 2009:232).

\section{Tujuan Pengendalian Intern}

Struktur pengendalian internal terdiri atas kebijakan dan prosedur yang dirancang untuk memberikan kepastian yang layak bagi manajemen, bahwa perusahaan telah mencapai tujuan dan sasarannya. Manajemen memiliki tiga tujuan umum dalam merancang sistem pengendalian internal yang efektif, yaitu keandalan pelaporan keuangan, efisiensi dan efektivitas operasi, serta ketaatan terhadap hukum dan peraturan. Manajemen bertanggung jawab untuk menyiapkan laporan bagi para investor, kreditur dan pengguna lainnya (Danang Sunyoto, 2014:157).

\section{Unsur Pengendalian Intern}

Struktur pengendalian internal perusahaan mencakup tiga kategori dasar kebijakan dan prosedur yang dirancang serta diimplementasikan manajemen guna memberikan kepastian yang layak bahwa tujuan pengendaliannya akan tercapai, meliputi lingkungan pengendalian, sistem akuntansi, dan prosedur pengendalian (Danang Sunyoto, 2014:161-166).

\section{Lingkungan Kendali}

Lingkungan kendali terdiri dari tindakan, kebijakan, dan prosedur yang mencerminkan keseluruhan sikap dari manajemen puncak,direktur,dan pemilik perusahaan dan pentingnya pengendalian bagi perusahaan tersebut.

\section{Sistem Akuntansi}

Tujuan dari sistem akuntansi adalah agar transaksi yang dicatat, diproses, dan dilaporkan telah memenuhi keenam tujuan audit umum atas transaksi

\section{Prosedur Pengendalian}

Aktivitas pengendalian berhubungan dengan penilaian atas mutu pengendalian internal secara berkesinambungan (berkala) oleh manajemen untuk menentukan bahwa pengendalian telah berjalan sebagaimana yang diharapkan, dan dimodifikasi sesuai dengan perkembangan kondisi yang ada dalam perusahaan.

\section{Keterbatasan Pengendalian Intern}

Berikut ini adalah keterbatasan bawaan yang melekat dalam setiap pengendalian intern:

1. Kesalahan dalam pertimbangan

2. Kemacetan

3. Kolusi 
4. Pelanggaran oleh manajemen

5. Biaya dan manfaat

\section{Kepatuhan \\ Pengertian Kepatuhan}

Menurut Alvin A.Arens dan James K.Loebbecke (2003:5) dalam Daniel Susanto (2007:32) mengungkapkan kepatuhan manajemen sebagai berikut:

"Kepatuhan manajemen merupakan suatu prosedur yang dijalankan manajemen untuk mengikuti prosedur atau peraturan yang telah ditetapkan oleh yang berwenang".

Menurut Agoes (2009:245) audit kepatuhan (compliance audit) harus dilakukan didalam perusahaan terhadap:

1. Kebijakan dan Prosedur Tertulis tentang Kelengkapan Transaksi

Hal ini dilakukan untuk membuktikan adanya kepatuhan terhadap kelengkapan transaksi yang dilakukan dalam perusahaan, pelaksanaan transaksi tersebut sejak transaksi dimulai sampai dengan selesai.

2. Kepatuhan terhadap Perundang-Undangan

Dalam setiap aspek operasional perusahaan atau bagian organisasi perusahaan harus memenuhi setiap peraturan perundang-undangan dan peraturan internal perusahaan.

\section{Tujuan Kepatuhan}

Adapun tujuan kepatuhan (compliance) menurut Alvin A.Arens dan James K.Loebbecke (2003:1) dalam Daniel Susanto (2007:32) adalah

"Tujuan kepatuhan (compliance) adalah untuk mempertimbangkan apakah klien (nasabah) telah mengikuti prosedur dan peraturan tertentu yang telah ditetapkan oleh pihak yang memiliki otoritas lebih tinggi”.

Manajemen dan bukan auditor yang harus menyusun dan memonitor struktur pengendalian internalnya. Konsep ini sesuai dengan ketentuan yang menyatakan bahwa manajemen dan bukan auditor yang bertanggung jawab dalam menyusun laporan-laporan sesuai dengan prinsip yang berlaku.

\section{Pengujian Kepatuhan}

Di hampir semua perusahaan swasta dan nirlaba, selalu terdapat kebijakan khusus, perjanjian, dan kewajiban hukum yang membutuhkan audit kepatuhan. Terdapat dua macam pengujian kepatuhan yaitu:

1. Pengujian adanya kepatuhan terhadap pengendalian intern.

2. Pengujian tingkat kepatuhan manajemen terhadap pengendalian intern.

\section{Etos Kerja}

\section{Pengertian Etos Kerja}

Menurut Jansen H.Sinamo (2005:2) dalam Inggri Krisnamurti (2012:17) menyatakan bahwa :

"Etos kerja adalah seperangkat perilaku kerja positif yang berakar pada kesadaran yang kental, keyakinan yang fundamental, disertai komitmen yang total pada paradigma kerja integral yang mencakup idealisme yang mendasari prinsip- 
prinsip yang mengatur, nilai-nilai yang menggerakkan, sikap-sikap yang melahirkan, standar-standar yang hendak dicapai, termasuk karakter utama, pikiran dasar, kode etik, kode moral dan kode perilaku bagi para pemeluknya".

\section{Aspek-Aspek Pengukuran Etos Kerja}

Delapan Etos Kerja Profesional menurut Jansen H.Sinamo (2005):

\section{Kerja adalah rahmat : bekerja tulus penuh syukur.}

Etos kerja pertama adalah percaya pada paradigma bahwa kerja adalah rahmat, dan karena itu harus disyukuri. Kerja sebagai rahmat membuat seseorang berlimpah dengan syukur. Secara khusus, seseorang dimampukan bekerja dengan hati bersih penuh keihklasan.

2. Kerja adalah amanah : bekerja benar penuh tanggung jawab.

Dari kesadaran amanah lahirlah kejiwaan moral yaitu tanggung jawab yang kemudian menumbuhkan keberanian moral dan keinginan kuat.

3. Kerja adalah panggilan : bekerja tuntas penuh integritas.

Dalam konteks pekerjaan, panggilan umum ini memiliki arti bahwa apa saja yang kita kerjakan hendaknya memenuhi tuntutan profesi. Profesi yang kita jalani untuk menjawab panggilan kita sebagai akuntan, hakim, dokter, dsb. Tujuan panggilan terpenting adalah agar manusia dapat bekerja tuntas dan selalu mengedepankan integritas.

4. Kerja adalah aktualisasi : bekerja keras penuh semangat.

Aktualisasi diri atau pengembangan potensi insani dapat terlaksana melalui pekerjaan, karena pekerjaan adalah pengerahan energi biologis, psikologis, dan spiritual yang selain membentuk karakter dan kompetensi manusia, Tujuan aktualisasi yang terpenting adalah agar manusia bisa bekerja keras dan selalu tuntas.

5. Kerja adalah ibadah : bekerja serius penuh kecintaan.

Kerja itu ibadah, yang intinya adalah tindakan memberi atau membaktikan harta, waktu, dan pikiran. Melalui pekerjaan, manusia dapat memiliki kepribadian, karakter, dan mental yang berkembang, dapat memperkaya hubungan silaturahmi yang saling mengasihi dan menyayangi, membangun rasa kesatuan antar manusia,menghasilkan kemakmuran, kesejahteraan dan kebahagiaan.

6. Kerja adalah seni : bekerja cerdas penuh kreativitas.

Kerja sebagai seni yang mendatangkan kesukaan dan gairah kerja bersumber pada aktivitas-aktivitas kreatif, artistik dan interaktif. Aktivitas seni menuntut penggunaan potensi kreatif dalam diri manusia, baik untuk menyelesaikan masalah-masalah kerja yang timbul maupun menggagas hal-hal baru.

7. Kerja adalah kehormatan : bekerja tekun penuh keunggulan.

Kerja sebagai kehormatan memiliki sejumlah dimensi yang sangat kaya

8. Kerja adalah pelayanan : bekerja paripurna penuh kerendahan hati. Tujuan pelayanan yang terpenting adalah agar manusia selalu bekerja paripurna dengan tetap rendah hati. Di dunia bisnis, melayani adalah ikhtiar tiada henti untuk memuaskan pelanggan dengan menyajikan karya-karya yang mengesankan dan produk-produk unggulan. 


\section{Faktor-faktor yang mempengaruhi Etos Kerja}

Faktor- faktor yang mempengaruhi Etos Kerja (Novliadi,2009):

1. Agama

2. Budaya

3. Sosial Politik

4. Kondisi Lingkungan/Geografis

5. Pendidikan

6. Struktur Ekonomi

7. Motivasi Intrinsik individu

\section{Cara Menumbuhkan Etos Kerja}

Etos kerja dapat tumbuh pada individu, masyarakat maupun organisasi dalam melaksanakan tugas dan fungsinya. Cara-cara untuk menumbuhkan etos kerja diantaranya : menumbuhkan sikap optimis, jadilah diri anda sendiri, keberanis untuk memulai, kerja dan waktu, konsentrasikan diri pada pekerjaan.

\section{Kompensasi Manajemen \\ Pengertian Kompensasi \\ Manajemen}

Menurut Malayu Hasibuan (2007: 118) kompensasi adalah imbalan jasa yang diberikan perusahaan kepada tenaga kerja karena telah memberikan sumbangan tenaga dan pikiran demi kemajuan dan kontinuitas perusahaan dalam rangka mencapai tujuan yang telah ditetapkan baik dalam jangka pendek maupun jangka panjang.

\section{Tujuan Pemberian Kompensasi Manajemen}

Menurut Malayu Hasibuan (2007:121-122), tujuan pemberian kompensasi (balas jasa) antara lain : sebagai ikatan kerja sama, kepuasan kerja, pengadaan efektif, motivasi, stabilitas karyawan, disiplin, serta pengaruh serikat buruh dan pemerintah.

\section{Faktor-Faktor yang Mempengaruhi Besarnya Kompensasi}

Menurut Malayu Hasibuan (2007:144), faktor-faktor yang mempengaruhi besarnya kompensasi diantaranya yaitu : penawaran dan permintaan tenaga kerja, kemampuan dan ketersediaan perusahaan permintaan, serikat buruh atau organisasi karyawan, produktivitas kerja karyawan, pemerintah dengan UndangUndang dan Keppresnya, biaya hidup, posisi jabatan, pendidikan dan pengalaman karyawan, kondisi perekonomian nasional, jenis dan sifat pekerjaan.

\section{Asas Kompensasi Manajemen}

Menurut Malayu Hasibuan (2007 : 122-123), program kompensasi (balas jasa) harus ditetapkan atas asas adil dan layak serta dengan memperhatikan undang-undang perburuhan yang berlaku. Prinsip adil dan layak harus mendapat perhatian dengan sebik-baiknya supaya balas jasa yang akan diberikan merangsang gairah dan kepuasan kerja karyawan. 


\section{Perilaku Etis Karyawan}

\section{Pengertian Etika dan Perilaku Etis Karyawan}

Menurut Ricky W.Griffin dan Ronald J.Ebert (2006:58) perilaku etis adalah perilaku yang sesuai dengan norma-norma sosial yang diterima secara umum sehubungan dengan tindakan-tindakan yang benar dan baik. Perilaku etis ini dapat menentukan kualitas individu (karyawan) yang dipengaruhi oleh faktor-faktor yang diperoleh dari luar yang kemudian menjadi prinsip yang dijalani dalam bentuk perilaku.

\section{Faktor-faktor yang mempengaruhi perilaku etis}

Faktor-faktor yang mempengaruhi perilaku etis:

1. Budaya organisasi

Budaya organisasi merupakan sistem makna bersama yang di anut oleh anggota-anggota yang membedakan organisasi itu dari organisai yang lain.

2. Kondisi politik

Kondisi politik merupakan rangkaian asas atau prinsip, keadaan, jalan cara atau alat yang akan digunakan untuk mencapai tujuan. Pencapaian itu dipengaruhi oleh perilaku-perilaku insan/individu atau kelompok guna memenuhi hak dan kewajibannya.

3. Perekonomian global

Perekonomian global merupakan kajian tentang pengurusan sumber daya material individu, masyarakat dan negara untuk meningkatkan kesejahteraan hidup manusia.

\section{Tanggung Jawab Terhadap Karyawan}

Menurut Ricky W.Griffin dan Ronald J.Ebert (2006:77-78) beberapa tanggung jawab perusahaan terhadap karyawan, diantaranya adalah:

\section{Komitmen Hukum dan Sosial}

Perilaku tanggung jawab secara sosial terhadap para karyawan memiliki komponen hukum dan sosial. Perusahaan dikatakan memenuhi tanggung jawab hukum dan sosialnya apabila karyawannya diberikan kesempatan yang sama tanpa memandang faktor-faktor suku, jenis kelamin, atau faktor lainnya yang tidak relevan.

\section{Komitmen Etis: kasus khusus para pengadu (Wishtle Blower)}

Menghargai karyawan sebagai manusia juga berarti menghagai perilaku mereka sebagai individu yang bertanggung jawab secara etis. Wishtle blower adalah karyawan yang mendeteksi dan berusaha mengakhiri tindakan perusahaan yang tidak etis, tidak ilegal atau tidak memiliki tanggung jawab sosial dengan cara mempublikasikannya.

\section{Prinsip-Prinsip Etis}

Menurut Alvin A.Arens (2006:108) terdapat beberapa prinsip etis, antara lain: tanggung jawab, kepentingan publik, integritas, objektivitas dan independensi, keseksamaan, ruang lingkup dan sifat jasa. 


\section{Penyebab Perilaku Tidak Etis}

Arens dan Loebbecke (1997:73) dalam Hesti Arlich (2012:19) menyebutkan bahwa, terdapat dua faktor utama yang mungkin menyebakan orang berperilaku tidak etis, yaitu:

1. Standar etika orang tersebut berbeda dengan masyarakat pada umumnya.

2. Orang tersebut secara sengaja bertindak tidak etis untuk keuntungan sendiri.

\section{METODOLOGI PENELITIAN \\ Desain Penelitian}

Desain penelitian yang digunakan adalah Penelitian Kausal Komparatif (Causal-Comparative Research). Penelitian kausal komparatif bertujuan untuk mengetahui pengaruh Variabel bebas (Independent Variable) adalah Pengendalian Intern, Kepatuhan, Etos Kerja dan Kompensasi Manajemen dan variabel terikat (Dependent Variable) adalah Perilaku Etis Karyawan.

\section{Variabel Penelitian}

Dalam penelitian ini terdapat dua variabel yang terdiri dari satu variabel independen (variabel bebas) dan satu variabel dependen (variabel terikat). Peneliti menggunakan 2 variabel yang akan diteliti yaitu:

1. Variabel Independen (Variabel $\mathrm{X}$ ) atau variabel bebas merupakan veriabel yang mempengaruhi atau yang menjadi sebab perubahannya atau timbulnya variabel dependen (terikat), dalam penelitian ini yang menjadi variabel " $\mathrm{X}$ " adalah "Pengendalian Intern $\left(\mathrm{X}_{1}\right)$, Kepatuhan $\left(\mathrm{X}_{2}\right)$, Etos Kerja $\left(\mathrm{X}_{3}\right)$, dan Kompensasi Manajemen $\left(\mathrm{X}_{4}\right)$ ".

2. Variabel Dependen (Variabel Y) variabel terikat merupakan variabel yang dipengaruhi atau yang menjadi akibat karena adanya variabel bebas. Yang menjadi variabel "Y" dalam penelitian ini adalah " Perilaku Etis Karyawan".

\section{Jenis Data}

Dalam penelitian ini peneliti menggunakan data primer untuk mengukur variabel independen (Pengendalian Intern, Kepatuhan, Etos Kerja, dan Kompensasi Manajemen) serta variabel dependen (Perilaku Etis Karyawan) yang diambil dari individu atau perseorangan, seperti hasil pengisian kuesioner.

\section{Populasi dan Sampel}

Populasi dari penelitian ini yaitu karyawan yang bekerja di Toko Buku Gamedia Central Park Jakarta. Peneliti menggunakan teknik pengambilan sampel secara non probabilitas (pemilihan nonrandom) dengan menggunakan metode purposive sampling yaitu merupakan teknik pengambilan sampel yang didasarkan atas pertimbangan-pertimbangan tertentu dari peneliti

Berdasarkan populasi dan sampel diatas, mengingat jumlah populasi diatas 100 karyawan maka dalam penelitian ini besar sampel $60 \%$ atau 75 karyawan dari jumlah populasi. 


\section{Operasional Variabel}

Operasional Variabel penelitian, peneliti uraikan dalam bentuk tabel 3.1 sebagai berikut:

Tabel 3.1

Operasional Variabel Penelitian

\begin{tabular}{|c|c|c|c|}
\hline Variabel & Sub Variabel & Indikator & Skala \\
\hline $\begin{array}{l}\text { Pengendalian } \\
\text { Intern }\left(\mathrm{X}_{1}\right) \\
\text { Sumber: Alvin } \\
\text { A.Arens } \\
(2006: 370)\end{array}$ & & $\begin{array}{l}\text { 1. Reabilitas Pelaporan } \\
\text { Keuangan } \\
\text { 2. Ketaatan pada Hukum dan } \\
\text { Peraturan } \\
\text { 3. Efisiensi dan Efektivitas } \\
\text { Operasi }\end{array}$ & Ordinal \\
\hline $\begin{array}{c}\text { Kepatuhan } \\
\left(\mathrm{X}_{2}\right) \text { Sumber : } \\
\text { Agoes } \\
(2009: 245) \\
\text { dalam Hesti } \\
\text { Arlich } \\
\text { Arifiyani } \\
\text { (2012) }\end{array}$ & & $\begin{array}{l}\text { 1. Kebijakan dan Prosedur } \\
\text { Tertulis tentang Kelengkapan } \\
\text { Transaksi } \\
\text { 2. Kepatuhan terhadap } \\
\text { Perundang-Undangan } \\
\text { Internal Perusahaan }\end{array}$ & Ordinal \\
\hline $\begin{array}{l}\text { Etos Kerja } \\
\quad\left(\mathrm{X}_{3}\right) \\
\text { Sumber : } \\
\text { Sinamo } \\
(2005: 98) \\
\text { dalam } \\
\text { Muhammad } \\
\text { Zulham (2008) }\end{array}$ & & $\begin{array}{l}\text { 1. Kerja sebagai rahmat } \\
\text { 2. Kerja sebagai amanah } \\
\text { 3. Kerja sebagai panggilan } \\
\text { 4. Kerja sebagai aktualisasi } \\
\text { 5. Kerja sebagai ibadah } \\
\text { 6. Kerja sebagai seni } \\
\text { 7. Kerja sebagai kehormatan } \\
\text { 8. Kerja sebagai pelayanan }\end{array}$ & Ordinal \\
\hline $\begin{array}{l}\text { Kompensasi } \\
\text { Manajemen } \\
\left(\mathrm{X}_{4}\right) \\
\text { Sumber : } \\
\text { Dessler } \\
(2009: 46)\end{array}$ & & $\begin{array}{l}\text { 1. Gaji } \\
\text { 2. Upah } \\
\text { 3. Insentif } \\
\text { 4. } \\
\text { Tunjangan }\end{array}$ & Ordinal \\
\hline $\begin{array}{l}\text { Perilaku Etis } \\
\text { Karyawan (Y) } \\
\text { Sumber : } \\
\text { Ricky } \\
\text { W.Griffin dan } \\
\text { Ronald J. } \\
\text { Ebert } \\
(2006: 58)\end{array}$ & & $\begin{array}{ll}\text { 1. } & \text { Budaya Organisasi } \\
\text { 2. } & \text { Kondisi Politik } \\
\text { 3. } & \text { Perekonomian Global }\end{array}$ & Ordinal \\
\hline
\end{tabular}




\section{Teknik Pengumpulan Data}

Metode Pengumpulan Data:

Kuesioner

Kuesioner (angket) merupakan teknik pengumpulan data yang dilakukan dengan cara memberi seperangkat pertanyaan atau pernyataan tertulis kepada responden untuk dijawab (Sugiyono,2009:142). Merupakan angket yang bersifat tertutup. Angket tertutup adalah suatu angket dimana pertanyaan dan alternatif jawabannya telah ditentukan sehingga responden tinggal memilih jawaban yang dianggap paling sesuai.

Skala yang digunakan adalah skala likert lima poin dengan rentang angka 1-5 yang memberikan gambaran sampai seberapa jauh responden melaksanakan fungsi sesuai dengan pertanyaan yang diberikan. Untuk setiap pilihan jawaban diberi skor, maka responden jawaban harus menggambarkan, mendukung pertanyaan atau tidak mendukung pertanyaan. Skor atas pilihan jawaban untuk kuesioner yang diajukan sebagai berikut :

$1=$ Sangat Tidak Setuju (STS)

$2=$ Tidak Setuju (TS)

$3=$ Kurang Setuju (KS)

$4=$ Setuju $(\mathrm{S})$

5 = Sangat Setuju (SS)

1. Wawancara

Wawancara merupakan teknik pengumpulan data dalam metode survey yang menggunakan pertanyaan secara lisan kepada subjek penelitian (Nur Indriantoro, 2009:152)..

\section{Metode Analisis data \\ Pengujian Instrumen Penelitian}

\section{Uji Reliabilitas}

Uji reliabilitas adalah alat untuk mengukur suatu kuesioner yang merupakan indikator dari variabel. Suatu kuesioner dikatakan reliabel atau handal jika jawaban seseorang terhadap pernyataan tersebut konsisten atau stabil dari waktu ke waktu. Dalam penelitian ini pengukuran dapat dilakukan dengan cara one shot atau penghitungan sekali, software Statistical Package for Social Science (SPSS) memberikan fasilitas untuk mengukur reliabilitas dengan uji statistik Cronbach Alpha $(\alpha)$. Suatu variabel dikatakan reliabel jika memberikan nilai Cronbach Alpha $>0,60$, sedangkan jika sebaliknya data tersebut dikatakan tidak reliabel (Imam Ghozali, 2005:41-42).

\section{Uji Validitas}

Uji Validitas adalah ukuran yang menunjukkan sejauh mana instrumen pengukuran mampu mengukur apa yang ingin diukur. Suatu kuesioner dikatakan valid jika pertanyaan pada kuesioner mampu untuk mengungkapkan sesuatu yang akan diukur oleh kuesioner tersebut. Validitas digunakan untuk mengetahui 
kesamaan antara data yang terkumpul dengan data yang sesungguhnya terjadi pada proyek yang diteliti, sehingga dapat diperoleh data yang valid. Pada program SPSS teknik pengujian yang sering digunakan dalam penelitian untuk uji validitas dapat dilihat melalui kolom Correlated Item-Total Correlation dengan membandingkan nilai Correlated Item-Total Correlation dengan hasil perhitungan $r_{\text {tabel }}$ (Imam Ghozali, 2005:45).

a. Koefisien validitas dianggap valid jika nilai $r_{\text {hitung }}>$ nilai $r_{\text {tabel }} \alpha=5 \%$.

b. Koefisien validitas dianggap tidak valid jika nilai $r_{\text {hitung }}<$ nilai $r_{\text {tabel }} \alpha=5 \%$.

\section{Uji Asumsi Klasik}

\section{Uji Normalitas}

Uji normalitas bertujuan untuk menguji apakah dalam model regresi, variabel terikat dan variabel bebas keduanya mempunyai distribusi normal ataukah tidak. Model regresi yang baik adalah memiliki distribusi data normal atau mendekati normal. Normalitas dapat diketahui dengan menggunakan uji statistik yaitu melihat tabel Kolmogorov - Smirnov Test (Imam Ghozali, 2005:30). Adapun kriteria pengujian adalah:

1. Apabila nilai signifikansi Komlogolov-Smirnov Test adalah lebih kecil dari 0,05 maka Ha diterima, sehingga data residual tidak berdistribusi normal.

2. Apabila nilai signifikansi Kolmogolov-Smirnov Test adalah lebih besar dari 0.05 maka Ha ditolak, sehingga data residual berdistribusi normal.

\section{Uji Multikolinieritas}

Uji multikolinieritas adalah uji yang bertujuan untuk menguji apakah pada model regresi ditemukan adanya korelasi antar variabel bebas (independen). Model regresi yang baik seharusnya tidak terjadi korelasi diantara variabel bebasnya. Untuk mendeteksi ada atau tidaknya multikolinieritas dalam suatu persamaan regresi adalah sebagai berikut: Besaran VIF (Variance Inflation Factor) dan Tolerance.

Dengan catatan : Tolerance $=1 /$ VIF atau bisa juga,

$$
\text { VIF } \quad=1 / \text { Tolerance }
$$

Nilai Tolerance yang rendah maka akan berakibat pada VIF yang tinggi (karena $\mathrm{VIF}=1$ / Tolerance), dan ini berarti terjadi multikolinieritas. Nilai tolerance yang umum dipakai untuk menunjukan adanya multikolinieritas adalah nilai Tolerance $<0,10$ atau sama dengan nilai VIF $>10$ (Imam Ghozali, 2005:92).

\section{Uji Heteroskedastisitas}

Uji Heteroskedastisitas bertujuan menguji apakah dalam model regresi terjadi ketidaksamaan variance dari residual satu pengamatan ke pengamatan yang lain. Model regresi yang baik adalah yang homoskedastisitas atau tidak terjadi Heteroskedastisitas. Dasar analisis ini adalah (Imam Ghozali, 2005 : 105) :

1. Jika ada pola tertentu, seperti titik-titik (point-point) yang ada membentuk suatu pola tertentu yang teratur (bergelombang, melebar kemudian menyempit), maka telah terjadi heteroskedastisitas.

2. Jika tidak ada pola yang jelas, serta titik-titik menyebar di atas dan di bawah angka 0 pada sumbu Y, maka tidak terjadi heteroskedastisitas. 


\section{Uji Auto Korelasi}

Autokorelasi merupakan korelasi antara anggota observasi yang disusun menurut waktu atau tempat. Model regresi yang baik seharusnya tidak terjadi autokorelasi.

\section{Analisis Korelasi}

Analisa Korelasi ini tidak membedakan jenis variabel (tidak ada variabel bebas ataupun terikat), keeratan hubungan ini dinyatakan dalam bentuk koefisien korelasi. Uji korelasi ini terdiri dari Pearson, Spearman, dan Kendall (Joko Sulistyo,2002:138).

\section{Analisis Regresi Linear Berganda}

Analisis regresi linear berganda berguna untuk menganalisa hubungan linear antara 2 variabel independen atau lebih dengan 1 variabel dependen (Duwi Priyatno, 2009:137). Dalam uji regresi peneliti menggunakan regresi berganda untuk mencari pengaruh antar variabel dengan rumus: (Duwi Priyatno, 2009:148)

Keterangan:

$$
\mathrm{Y}=\mathrm{a}+\beta_{1} \mathrm{X}_{1}+\beta_{2} \mathrm{X}_{2}+\beta_{3} \mathrm{X}_{3}+\beta_{4} \mathrm{X}_{4}+\varepsilon
$$

Y : Perilaku Etis Karyawan

a : Nilai konstanta nilai $Y$ jika $X=0$

$\beta$ : Nilai arah sebagai penentu ramalan (prediksi) yang menunjukan nilai peningkatan (+) atau penurunan (-) $\mathrm{Y}$

$\mathrm{X}_{1}$ : Pengendalian Intern

$\mathrm{X}_{2}$ : Kepatuhan

$\mathrm{X}_{3}$ : Etos Kerja

$\mathrm{X}_{4}$ : Kompensasi Manajemen

$\varepsilon$ : Variabel lain yang mempengaruhi $\mathrm{Y}$

\section{Uji Hipotesis}

\section{Pengujian Hipotesis Secara Parsial (Uji t)}

Untuk mengetahui signifikan pengaruh atau hubungan antara variabel dilakukan dengan kriteria pengujian sebagai berikut: (Imam Ghozali, 2005:58)

1. Jika nilai probabilitas (sig.) pada tabel coefficient output SPSS > nilai probabilitas 0,05 atau $t_{\text {hitung }}<t_{\text {tabel }}$, maka Ho diterima dan Ha ditolak.

2. Jika nilai probabilitas (sig.) pada tabel coefficient output SPSS < nilai probabilitas 0,05 atau $t_{\text {hitung }}>t_{\text {tabel, }}$, maka Ho ditolak dan Ha diterima.

\section{Pengujian Hipotesis Secara Simultan (Uji F)}

Untuk mengetahui signifikansi analisis jalur bandingkan antara nilai probabilitas signifikan dengan nilai probabilitas 0,05 sebagai dasar pengambilan keputusan sebagai berikut: (Imam Ghozali, 2005:60)

1. Jika nilai probabilitas ( sig.) pada tabel Anova output SPSS $>$ nilai probabilitas 0,05 atau $\mathrm{F}_{\text {hitung }}<\mathrm{F}_{\text {tabel, }}$ maka Ho diterima dan Ha ditolak.

2. Jika nilai probabilitas ( sig.) pada tabel Anova output SPSS $<$ nilai probabilitas 0,05 atau $F_{\text {hitung }}>F_{\text {tabel}}$, maka Ho ditolak dan Ha diterima. 
Selanjutnya untuk menyatakan besar kecilnya sumbangan variabel $X$ terhadap $\mathrm{Y}$ dapat ditentukan dengan rumus koefisien determinasi $\left(\mathrm{R}^{2}\right)$. Nilai koefisien determinan adalah nol dan satu. Nilai $\mathrm{R}^{2}$ yang lebih kecil berarti kemampuan variabel-variabel independen dalam menjelaskan variasi variabel dependen amat terbatas. Nilai yang mendekati satu berarti variabel-variabel independen memberikan hampir semua informasi yang dibutuhkan untuk memprediksi variasi variabel dependen (Imam Ghozali, 2005:83).

\section{ANALISIS HASIL DAN PEMBAHASAN}

\section{Pengujian Instrumen Penelitian}

\section{Uji Reabilitas}

Seluruh Cronbach's Alpha $\geq 0.60$. Dapat disimpulkan bahwa pernyataanpernyataan dalam variabel pengendalian intern, kepatuhan, etos kerja, kompensasi manajemen dan perilaku etis karyawan adalah reliabel, artinya bahwa hasil pengukuran variabel-variabel tersebut adalah konsisten.

\section{Uji Validitas}

Untuk masing-masing item atau butir pernyataan nilainya $>r_{\text {tabel }} 0,2272$, sehingga dapat disimpulkan bahwa pernyataan untuk variabel pengendalian intern, kepatuhan, etos kerja, kompensasi manajemen dan perilaku etis karyawan adalah valid.

\section{Uji Asumsi}

\section{Klasik}

Tabel 4.3

One-Sample Kolmogorov-Smirnov Test

\begin{tabular}{|c|c|c|c|c|c|c|}
\hline & & $\begin{array}{l}\text { pengend } \\
\text { alian_in } \\
\mathrm{t} \\
\text { ern }\end{array}$ & $\begin{array}{l}\text { Kepatuh } \\
\text { an }\end{array}$ & $\underset{\mathrm{j}}{\operatorname{eto}}$ & $\begin{array}{l}\text { kompens } \\
\text { a } \\
\text { si_manaj } \\
\text { e } \\
\text { men }\end{array}$ & $\begin{array}{l}\text { perilaku_e } \\
\text { tis_karyaw } \\
\text { an }\end{array}$ \\
\hline $\mathrm{N}$ & & 75 & 75 & 75 & 75 & 75 \\
\hline Normal & Mean & 499,9999 & 500,0003 & 486,0365 & 500,0004 & 600,0000 \\
\hline $\begin{array}{l}\text { Parameters } \\
\mathrm{a}, \mathrm{b}\end{array}$ & $\begin{array}{l}\text { Std. } \\
\text { Devi } \\
\text { ation }\end{array}$ & 55,72299 & 55,19491 & 52,71738 & 55,78131 & 66,03250 \\
\hline $\begin{array}{l}\text { Most } \\
\text { Extreme }\end{array}$ & $\begin{array}{l}\text { Abso } \\
\text { lute }\end{array}$ & , 105 & ,119 & , 102 & ,079 & ,092 \\
\hline $\begin{array}{l}\text { Difference } \\
\mathrm{s}\end{array}$ & $\begin{array}{l}\text { Positi } \\
\text { ve }\end{array}$ & ,069 & ,119 & ,102 & ,079 & ,090 \\
\hline & $\begin{array}{l}\text { Nega } \\
\text { tive }\end{array}$ &,- 105 &,- 093 &,- 059 &,- 078 &,- 092 \\
\hline $\begin{array}{l}\text { Kolmogoro } \\
\text { Smirnov Z }\end{array}$ & & ,907 & 1,027 & ,880 & ,687 & ,796 \\
\hline $\begin{array}{l}\text { Asymp. Sig } \\
\text { tailed) }\end{array}$ & & ,382 & ,242 & ,421 & ,733 & ,550 \\
\hline
\end{tabular}




\section{Uji Normalitas}

Berdasarkan table 4.3 diatas, diperoleh hasil Asymp. Sig. (2-tailed) untuk variabel Pengendalian Intern $\left(X_{1}\right)=0,382>0,05$, Kepatuhan $\left(X_{2}\right)=0,242>0,05$, Etos Kerja $\left(\mathrm{X}_{3}\right)=0,421>0,05$, Kompensasi Manajemen $\left(\mathrm{X}_{4}\right)=0.733>0,05$, dan Perilaku Etis Karyawan $(\mathrm{Y})=0,550>0,05$, maka dapat disimpulkan data yang diambil dari populasi berdistribusi normal.

\section{Uji Multikolinearitas}

Tabel 4.4

Coefficients $^{\mathrm{a}}$

\begin{tabular}{|ll|r|r|}
\hline \multicolumn{2}{|l|}{ Model } & \multicolumn{2}{|c|}{ Collinearity Statistics } \\
\cline { 3 - 4 } & & \multicolumn{1}{|c|}{ Tolerance } & \multicolumn{1}{c|}{ VIF } \\
\hline \multirow{2}{*}{1} & (Constant) &, 253 & \\
1 & pengendalian_intern &, 446 & 3,960 \\
& Kepatuhan &, 191 & 2,241 \\
& etos_kerja &, 176 & 5,227 \\
& kompensasi_manajemen & 5,681 \\
\hline
\end{tabular}

a. Dependent Variable: perilaku_etis_karyawan

Berdasarkan tabel 4.4 diatas, dapat diketahui bahwa nilai Variance Inflation Factor (VIF) variabel pengendalian intern, kepatuhan, etos kerja, kompensasi manajemen dan perilaku etis karyawan adalah lebih kecil dari 10, dan nilai tolerance diatas $10 \%$ sehingga dapat disimpulkan bahwa antar variabel independen tidak terjadi persoalan multikolinearitas.

\section{Uji Heteroskedastisitas}

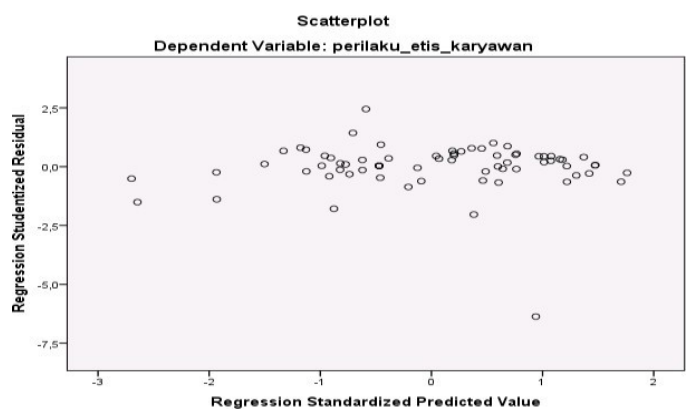

Gambar 4.1

Berdasarkan gambar 4.1 diatas, dapat diketahui bahwa titik-titik tidak terbentuk pola yang jelas dan titik-titik menyebar di atas dan di bawah angka 0 pada sumbu Y maka dapat disimpulkan bahwa tidak terjadi heteroskedastisitas dalam model regresi. 


\section{Uji Autokorelasi}

Tabel 4.5

Model Summary

\begin{tabular}{|l|r|r|r|r|r|}
\hline $\begin{array}{l}\text { Mode } \\
1\end{array}$ & R & R Square & $\begin{array}{c}\text { Adjusted R } \\
\text { Square }\end{array}$ & $\begin{array}{c}\text { Std. Error of } \\
\text { the Estimate }\end{array}$ & $\begin{array}{l}\text { Durbin- } \\
\text { Watson }\end{array}$ \\
\hline 1 &, $856^{\mathrm{a}}$ &, 733 &, 717 & 35,09830 & 1,791 \\
\hline
\end{tabular}

a. Predictors: (Constant), kompensasi_manajemen,

kepatuhan, pengendalian intern, etos kerja

b. Dependent Variable: perilaku_etis_karyawan

Berdasarkan tabel 4.5 diatas, didapat nilai DW yang dihasilkan dari model regresi adalah 1,791. Karena nilai DW terletak antara dU 1,7390 dan (4 - dU) 2,261, maka hipotesis nol diterima yang berarti tidak ada autokorelasi.

\section{Analisis Korelasi}

\section{Tabel 4.6 Correlations}

\begin{tabular}{|c|c|c|c|c|c|c|}
\hline & & $\begin{array}{l}\text { pengen } \\
\text { dalian_- } \\
\text { intern }\end{array}$ & $\begin{array}{c}\text { Kepat } \\
\mathrm{u} \\
\text { han }\end{array}$ & $\begin{array}{l}\text { etos_ } \\
\mathrm{k} \\
\text { erja }\end{array}$ & $\begin{array}{l}\text { kompe } \\
\mathrm{n} \\
\text { sasi_m } \\
\text { a } \\
\text { najemen }\end{array}$ & $\begin{array}{l}\text { perilaku } \\
\text { etis_kary } \\
\text { awan }\end{array}$ \\
\hline \multirow{5}{*}{ pengendalian_intern } & Pearson & 1 &, $728^{* *}$ &, $796^{* *}$ & $821^{* *}$ &, $769^{* *}$ \\
\hline & $\begin{array}{l}\text { Correlatio } \\
\mathrm{n}\end{array}$ & & & & & \\
\hline & $\begin{array}{l}\text { Sig. }(2- \\
\text { tailed) }\end{array}$ & &, 000 &, 000 &, 000 & 000 \\
\hline & $\mathrm{N}$ & 75 & 75 & 75 & 75 & 75 \\
\hline & $\begin{array}{l}\text { Pearson } \\
\text { Correlation }\end{array}$ &, $728^{* *}$ & 1 &, $670^{* *}$ &, $645^{* *}$ &, $518^{* *}$ \\
\hline \multirow[t]{3}{*}{ Kepatuhan } & $\begin{array}{l}\text { Sig. }(2- \\
\text { tailed) }\end{array}$ &, 000 & &, 000 &, 000 &, 000 \\
\hline & $\mathrm{N}$ & 75 & 75 & 75 & 75 & 75 \\
\hline & $\begin{array}{l}\text { Pearson } \\
\text { Correlation }\end{array}$ &, $796^{* *}$ &, $670^{* *}$ & 1 &, $888^{* *}$ &, $806^{* *}$ \\
\hline \multirow[t]{3}{*}{ etos_kerja } & $\begin{array}{l}\text { Sig. }(2- \\
\text { tailed) }\end{array}$ &, 000 & ,000 & &, 000 &, 000 \\
\hline & $\mathrm{N}$ & 75 & 75 & 75 & 75 & 75 \\
\hline & $\begin{array}{l}\text { Pearson } \\
\text { Correlation }\end{array}$ &, $821^{* *}$ &, $645^{* *}$ &, $888^{* *}$ & 1 &, $818^{* *}$ \\
\hline \multirow[t]{2}{*}{ kompensasi_manajemen } & $\begin{array}{l}\text { Sig. }(2- \\
\text { tailed })\end{array}$ &, 000 &, 000 &, 000 & &, 000 \\
\hline & $\mathrm{N}$ & 75 & 75 & 75 & 75 & 75 \\
\hline **. Correlation is signifi & $\begin{array}{l}\text { Pearson } \\
\text { arforreteatio.0 } \\
n\end{array}$ & $\begin{array}{l}, 769^{* *} \\
\text { level (2 }\end{array}$ & $\begin{array}{l}, 518^{* *} \\
\text { tailed). }\end{array}$ &, $806^{* *}$ &, $818^{* *}$ & 1 \\
\hline
\end{tabular}


Berdasarkan tabel 4.6, selanjutnya peneliti melakukan interprestasi hubungan masing-masing variabel penelitian yaitu sebagai berikut:

1) Pengendalian Intern memiliki korelasi yang kuat yaitu $76,9 \%$ terhadap Perilaku Etis Karyawan.

2) Kepatuhan memiliki korelasi yang kuat yaitu 51,8\% terhadap Perilaku Etis Karyawan.

3) Etos Kerja memiliki korelasi yang kuat yaitu 80,6\% terhadap Perilaku Etis Karyawan.

4) Kompensasi Manajemen memiliki korelasi yang kuat yaitu $81,8 \%$ terhadap Perilaku Etis Karyawan.

5) Pengendalian Intern memiliki korelasi yang kuat yaitu $72,8 \%$ terhadap Kepatuhan.

6) Pengendalian Intern memiliki korelasi yang kuat yaitu $79,6 \%$ terhadap Etos Kerja.

7) Pengendalian Intern memiliki korelasi yang kuat yaitu $82,1 \%$ terhadap Kompensasi Manajemen.

8) Kepatuhan memiliki korelasi yang cukup kuat yaitu 67\% terhadap Etos Kerja.

9) Kepatuhan memiliki korelasi yang kuat yaitu 64,5\% terhadap Kompensasi Manajemen.

10) Kepatuhan memiliki korelasi yang kuat yaitu $88,8 \%$ terhadap Kompensasi Manajemen

Analisis Regresi Linear Berganda

Tabel 4.7

Coefficients $^{\mathrm{a}}$

\begin{tabular}{|c|c|c|c|c|c|c|c|c|}
\hline \multirow[t]{2}{*}{ Model } & & \multicolumn{2}{|c|}{$\begin{array}{l}\text { Unstandardize } \\
\text { d Coefficients }\end{array}$} & \multirow{2}{*}{$\begin{array}{c}\text { Standardi } \\
\text { z ed } \\
\text { Coefficie } \\
n \\
\text { ts } \\
\text { Beta }\end{array}$} & \multirow[t]{2}{*}{$\mathrm{T}$} & \multirow[t]{2}{*}{ Sig. } & \multicolumn{2}{|c|}{$\begin{array}{l}\text { Collinearit } \\
\text { y } \\
\text { Statistics }\end{array}$} \\
\hline & & B & $\begin{array}{l}\text { Std. } \\
\text { Erro } \\
\mathrm{r}\end{array}$ & & & & $\begin{array}{l}\text { Tol } \\
\text { era } \\
\mathrm{n} \\
\text { ce } \\
\end{array}$ & VIF \\
\hline \multirow{6}{*}{1} & (Constant) & 91,135 & 41,387 & & 2,202 &, 031 & & \\
\hline & $\begin{array}{l}\text { pengendali } \\
\text { a n_intern }\end{array}$ & ,404 & ,146 & ,341 & 2,775 & ,007 & ,253 & 3,960 \\
\hline & Kepatuhan &,- 229 & ,111 &,- 192 & & ,042 & ,446 & 2,241 \\
\hline & & & & & $\begin{array}{l}2,07 \\
2\end{array}$ & & & \\
\hline & etos_kerja & , 444 & , 177 & ,354 & 2,508 & ,014 & , 191 & 5,226 \\
\hline & $\begin{array}{l}\text { kompensasi } \\
\text { manajem } \\
\text { e n }\end{array}$ & ,411 & ,174 & ,347 & 2,359 & 021 & 176 & 5,680 \\
\hline
\end{tabular}

a. Dependent Variable: perilaku_etis_karyawan Sunber data : Output SPSS 


$$
\begin{aligned}
& \mathrm{Y}=a+\beta_{1} \mathrm{X}_{1}+\beta_{2} \mathrm{X}_{2}+\beta_{3} \mathrm{X}_{3}+\beta_{4} \mathrm{X}_{4}+\varepsilon \\
& \mathrm{Y}=91,135+0,341 \mathrm{X}_{1}-0,192 \mathrm{X}_{2}+0,354 \mathrm{X} 3+0,347 \mathrm{X}_{4}+\varepsilon
\end{aligned}
$$


Persamaan regresi linear diatas dapat dijelaskan sebagai berikut :

1. Nilai konstanta $(a)$ adalah 91,135 artinya jika pengendalian intern $\left(\mathrm{X}_{1}\right)$, kepatuhan $\left(\mathrm{X}_{2}\right)$, etos kerja $\left(\mathrm{X}_{3}\right)$, dan kompensasi manajemen $\left(\mathrm{X}_{4}\right)$ bernilai 0, maka Perilaku Etis Karyawan (Y) bernilai positif 91,135.

2. Nilai koefisien regresi variabel pengendalian intern $\left(\mathrm{X}_{1}\right)$ bernilai positif sebesar 0,341 artinya bahwa setiap peningkatan pengendalian intern sebesar 1, maka perilaku etis karyawan (Y) juga akan meningkat sebesar 0.341 .

3. Nilai koefisien regresi variabel kepatuhan $\left(\mathrm{X}_{2}\right)$ bernilai negatif sebesar $-0,192$ artinya bahwa kepatuhan mempunyai hubungan yang berlawanan arah dengan perilaku etis karyawan, setiap peningkatan kepatuhan sebesar 1, maka perilaku etis karyawan (Y) akan menurun sebesar 0,192.

4. Nilai koefisien regresi variabel etos kerja (X3) bernilai positif sebesar 0.354 ini artinya bahwa setiap peningkatan etos kerja sebesar 1, maka perilaku etis karyawan (Y) juga akan meningkat sebesar 0.354 .

5. Nilai koefisiensi regresi variabel kompensasi manajemen (X4) bernilai positif, yaitu sebesar 0,347, artinya bahwa setiap peningkatan kompensasi manajemen sebesar 1 , maka perilaku etis karyawan juga akan meningkat sebesar 0.347 .

\section{Pengujian Hipotesis}

\section{Pengujian Hipotesis Secara Parsial (Uji t)}

Berdasarkan tabel 4.7 diatas :

1) Diperoleh $t_{\text {hitung }}$ pengendalian intern sebesar 2,775 dengan tingkat signifikansi 0,007 , kemudian dibandingkan dengan $t_{\text {tabel }}$ sebesar 1,994 ternyata nilai $t_{\text {hitung }}(2,775)$ $>t_{\text {tabel }}(1,994)$, maka $H_{o}$ ditolak dan $\mathrm{H}_{\mathrm{a}}$ diterima, artinya bahwa pengendalian intern berpengaruh terhadap perilaku etis karyawan.

2) Diperoleh $t_{\text {hitung }}$ kepatuhan sebesar -2,072 dengan tingkat signifikansi $<0,05(0,042$ $<0,05)$ maka $\mathrm{H}_{\mathrm{o}}$ diterima dan $\mathrm{H}_{\mathrm{a}}$ ditolak, kemudian dibandingkan dengan $\mathrm{t}_{\text {tabel }}$ sebesar 1,994 ternyata nilai $t_{\text {hitung }}(-2,072)<t_{\text {tabel }}(1,994)$, artinya bahwa kepatuhan berpengaruh negatif terhadap perilaku etis karyawan.

3) Diperoleh $t_{\text {hitung }}$ etos kerja sebesar 2,508 dengan tingkat signifikansi 0,014 , kemudian dibandingkan dengan $t_{\text {tabel }}$ sebesar 1,994 ternyata nilai $t_{\text {hitung }}(2,508)>t_{\text {tabel }}$ $(1,994)$, maka $\mathrm{H}_{\mathrm{o}}$ ditolak dan $\mathrm{H}_{\mathrm{a}}$ diterima, artinya bahwa etos kerja berpengaruh terhadap perilaku etis karyawan.

4) Diperoleh $t_{\text {hitung }}$ kompensasi manajemen sebesar 2,359 dengan tingkat signifikansi 0,021 , kemudian dibandingkan dengan $t_{\text {tabel }}$ sebesar 1,994 ternyata nilai $t_{\text {hitung }}(2,359)$ $>t_{\text {tabel }}(1,994)$, maka $H_{0}$ ditolak dan $H_{a}$ diterima, artinya bahwa kompensasi manajemen berpengaruh terhadap perilaku etis karyawan.

Berdasarkan hasil tabel 4.8 diatas bahwa hasil $\mathrm{F}_{\text {hitung }}$ sebesar 47,980 dengan tingkat signifikansi $0,000^{\mathrm{b}}$, artinya $\mathrm{F}_{\text {hitung }}>\mathrm{F}_{\text {tabel }}(47,980>2,503)$, dengan demikian Ho ditolak dan Ha diterima yang berarti pengendalian intern, kepatuhan, etos kerja, dan kompensasi manajemen secara bersama-sama berpengaruh terhadap perilaku etis karyawan. 


\section{Pengujian Hipotesis Secara Simultan (Uji F)}

Tabel 4.8

ANOVA $^{\mathrm{a}}$

\begin{tabular}{|rl|r|r|r|r|r|}
\hline \multicolumn{1}{|l|}{ Model } & \multicolumn{1}{|c|}{$\begin{array}{c}\text { Sum of } \\
\text { Squares }\end{array}$} & Df & \multicolumn{1}{c|}{$\begin{array}{c}\text { Mean } \\
\text { Square }\end{array}$} & F & Sig. \\
\hline \multirow{2}{*}{1} & Regression & 236424,575 & 4 & 59106,144 & 47,980 &, $000^{\mathrm{b}}$ \\
& Residual & 86232,349 & 70 & 1231,891 & & \\
& Total & 322656,924 & 74 & & & \\
\hline
\end{tabular}

Tabel 4.9

Model Summary ${ }^{\mathrm{b}}$

\begin{tabular}{|l|r|r|r|r|r|}
\hline $\begin{array}{l}\text { Mode } \\
1\end{array}$ & $\mathrm{R}$ & R Square & $\begin{array}{c}\text { Adjusted R } \\
\text { Square }\end{array}$ & $\begin{array}{c}\text { Std. Error of } \\
\text { the Estimate }\end{array}$ & $\begin{array}{l}\text { Durbin- } \\
\text { Watson }\end{array}$ \\
\hline 1 &, $856^{\mathrm{a}}$ &, 733 &, 717 & 35,09830 & 1,791 \\
\hline
\end{tabular}

Nilai koefisien determinasi (Adj R) yang diperoleh sebesar 0,733. Dari hasil perhitungan diatas, dapat disimpulkan bahwa pengendalian intern, kepatuhan, etos kerja, dan kompensasi manajemen berpengaruh positif dan signifikan terhadap perilaku etis karyawan sebesar $73,3 \%$, sedangkan sisanya sebesar $26,7 \%$ dipengaruhi oleh faktor lain di luar model penelitian.

\section{Interprestasi Hasil Penelitian}

Pengendalian Intern $\left(\mathrm{X}_{1}\right)$ Berpengaruh Secara Signifikan Terhadap Perilaku Etis Karyawan (Y)

Hasil penelitian ini menunjukkan bahwa pengendalian intern memiliki pengaruh yang positif dan signifikan terhadap perilaku etis karyawan sebesar 2,775 dengan signifikan $0,007<0,05$. Artinya tinggi rendahnya Perilaku Etis

Hasil penelitian ini konsisten dengan penelitian sebelumnya yang dilakukan oleh Hesti Arlich Arifiyani (2012) yang berjudul "Pengaruh Pengendalian Intern, Kepatuhan, dan Kompensasi Manajemen terhadap Perilaku Etis Karyawan" menunjukkan bahwa pengendalian intern berpengaruh secara positif dan signifikan terhadap perilaku etis karyawan.

\section{Kepatuhan $\left(\mathbf{X}_{2}\right)$ Berpengaruh Negatif terhadap Perilaku Etis Karyawan (Y)}

Hasil penelitian ini menunjukkan bahwa berdasarkan nilai signifikansi $0,042<$ 0,05 maka dapat disimpulkan kepatuhan memiliki pengaruh terhadap perilaku etis karyawan, berdasarkan $\mathrm{t}$ hitung yang diperoleh sebesar $-2,072<\mathrm{t}$ tabel 1,994 dapat disimpulkan bahwa kepatuhan memiliki hubungan berlawanan arah (negatif) dengan perilaku etis karyawan, setiap peningkatan kepatuhan sebesar 1 maka perilaku etis karyawannya akan menurun sebesar koefisien regresi yaitu sebesar 0,192, itu sangat berpengaruh dengan perilaku etis karyawannya, tetapi aturan dan standar yang telah ditetapkan itu apabila terlalu mengekang dan membuat orang tersebut tidak nyaman serta dari dalam diri orang tersebut secara sengaja enggan untuk bertindak tidak etis maka kepatuhan menjadi berlawanan arah dengan perilaku etis. 


\section{Etos Kerja $\left(\mathbf{X}_{3}\right)$ Berpengaruh Secara Signifikan terhadap Perilaku Etis Karyawan}

(Y)

Hasil penelitian ini menunjukkan bahwa etos kerja memiliki pengaruh yang positif dan signifikan terhadap perilaku etis karyawan sebesar 2,508 dengan signifikan 0,014< 0,05. Artinya tinggi rendahnya Perilaku Etis Karyawan yang dihasilkan dapat dijelaskan oleh Etos Kerja, setiap peningkatan etos kerja maka perilaku etis karyawannya juga akan meningkat.

\section{Kompensasi Manajemen $\left(\mathrm{X}_{4}\right)$ Berpengaruh Secara Signifikan terhadap Perilaku Etis Karyawan (Y)}

Hasil penelitian ini menunjukkan bahwa kompensasi manajemen memiliki pengaruh yang positif dan signifikan terhadap perilaku etis karyawan sebesar 2,359 dengan signifikan $0,021<0,05$. Artinya tinggi rendahnya Perilaku Etis Karyawan yang dihasilkan dapat dijelaskan oleh Kompensasi Manajemen, setiap peningkatan kompensasi manajemen maka perilaku etis karyawannya juga akan meningkat.

Pengendalian Intern (X1), Kepatuhan $\left(X_{2}\right)$, Etos Kerja $\left(X_{3}\right)$ dan Kompensasi Manajemen $\left(\mathrm{X}_{4}\right)$ Secara Bersama- sama Berpengaruh Signifikan terhadap Perilaku Etis Karyawan (Y)

Hasil penelitian ini menunjukkan bahwa pengendalian intern, kepatuhan, etos kerja dan kompensasi manajemen memiliki pengaruh yang positif dan signifikan terhadap perilaku etis karyawan sebesar 0,733 dengan signifikan 0,000 $<0,05$. Artinya pengendalian intern, kepatuhan, etos kerja, dan kompensasi manajemen berpengaruh positif dan signifikan terhadap perilaku etis karyawan sebesar $73,3 \%$, sedangkan sisanya sebesar 26,7\% dipengaruhi oleh faktor lain di luar model penelitian. Hasil penelitian ini dapat diinterpretasikan bahwa pengendalian intern, kepatuhan, etos kerja, dan kompensasi manajemen memiliki korelasi terhadap perilaku etis karyawan sebesar $73,3 \%$.

\section{KESIMPULAN DAN SARAN \\ Kesimpulan}

Setelah dilakukan penelitian, maka diperoleh hasil analisis terhadap hipotesa pertama, kedua, ketiga, keempat dan kelima sebagai berikut :

1. Pengendalian Intern berpengaruh secara signifikan dan memiliki nilai positif terhadap perilaku etis karyawan.

2. Kepatuhan berpengaruh secara signifikan dan memiliki nilai negatif terhadap perilaku etis karyawan.

3. Etos kerja berpengaruh secara signifikan dan memiliki nilai positif terhadap perilaku etis karyawan.

4. Kompensasi manajemen berpengaruh secara signifikan dan memiliki nilai positif terhadap perilaku etis karyawan.

5. Pengendalian Intern, Kepatuhan, Etos Kerja dan Kompensasi Manajemen secara bersama-sama berpengaruh secara signifikan dan memiliki nilai positif terhadap perilaku etis karyawan. 


\section{Saran}

Harapan peneliti pada penelitian selanjutnya diharapkan dapat memperbaiki kekurangan-kekurangan penelitian ini diantaranya :

1. Melakukan penelitian dalam lingkup yang lebih luas dengan waktu yang cukup sehingga dapat diperoleh data yang cukup dan hasil analisa akan jauh lebih akurat.

2. Responden yang diambil sebagai sampel jumlahnya harus lebih besar dari sampel penelitian ini, sehingga proses pengolahan data, analisis data, dan interprestasi hasil akan jauh lebih baik dari penelitian ini.

3. Mengembangkan penelitian dengan menambahkan faktor-faktor dan variabel lain diluar model penelitian ini yang mempunyai pengaruh terhadap perilaku etis karyawan, sehingga dapat memberikan gambaran yang lebih luas mengenai faktor apa saja yang mempengaruhi perilaku etis karyawan selain Pengendalian Intern, Kepatuhan, Etos Kerja dan Kompensasi Manajemen.

\section{DAFTAR PUSTAKA}

Arens, Alvin. 2006. Auditing dan Jasa Assurance, Jilid I. Jakarta: Erlangga

Amin Widjaja Tunggal. 2010. Key Concepts in Auditing and Assurance Services.Jakarta:Harvarindo

Danang Sunyoto. 2014. Auditing Pemeriksaan Akuntansi. Jakarta: Buku Kita

Daniel Susanto. 2007. Peranan Audit Internal Terhadap Kepatuhan Manajemen

Perusahaan. Skripsi. Universitas Widyatama

Dessler,Gary.2007. Manajemen Sumber Daya Manusia Jilid II. Jakarta : Indeks

Duwi Prayitno.2009. 5 Jam Belajar Olah Data SPSS 17. Yogyakarta:Andi

Griffin, Ricky and Ronald J.Ebert.2006. Bisnis Edisi kedelapan. Jakarta: Erlangga

Hesti Arlich Arifiyani dkk. 2012. Pengaruh Pengendalian Intern,Kepatuhan, dan Kompensasi Manajemen terhadap Perilaku Etis Karyawan. Skripsi. Universitas Negeri Yogyakarta.

Imam Ghozali. 2005. Aplikasi Analisis Multivariate dengan Program SPSS. Semarang: Badan Penerbit Universitas Diponegoro.

Joko Sulistyo. 2002. 6 Hari Jago SPSS 17. Jogjakarta : Cakrawala

Malayu Hasibuan.2007. Manajemen Sumber Daya Manusia. Jakarta: PT Bumi Aksara. Mohammad Glifandi. 2011. Analisis Pengaruh Keefekifan Pengendalian Internal,

Persepsi Kesesuaian Kompensasi, Moralitas Manajemen Terhadap Perilaku

Tidak Etis dan Kecenderungan Kecurangan Akuntansi. Skripsi. Universitas Diponegoro Semarang.

Mulyadi. 2006. Auditing . Jakarta: Salemba Empat

Novliadi.2009. Hubungan Antara Organization-Based Self-Esteem dengan Etos Kerja. Skripsi. Universitas Sumatera Utara Medan.

Sinamo, Jansen H. 2005. Delapan Etos Kerja Profesional: Navigator Anda menjadi sukses cetakan kelima. Jakarta : Institut Darma Mahardika.

Sugiyono. 2009. Metode Penelitian Kuantitatif, Kualitatif dan R\&D. Bandung:

Alfabeta.

Sukrisno Agoes dan Jan Hoesada. 2009. Bunga Rampai Auditing. Jakarta: Salemba Empat.

Wawan Ridwan Mutaqin. 2010. Pengaruh Iklim Organisasi, Etos Kerja dan Disiplin Kerja Terhadap Efektifitas Kinerja Organisasi. Skripsi. Universitas Sebelas Maret Surakarta. 